\title{
Association of Functional Dyspepsia with Depression and Anxiety: A Systematic Review
}

\author{
Tasia Esterita, Sheilla Dewi, Felicia Grizelda Suryatenggara, Glenardi Glenardi
}

Faculty of Medicine and

Health Sciences, Atma

Jaya Catholic University of Indonesia, Pluit Raya No.

2, North Jakarta 14440,

Indonesia
Received: 17.12 .2020

Accepted: 02.03.2021

\begin{abstract}
Background \& Aims: Functional dyspepsia (FD) symptoms may lead to depression or anxiety in affected individuals and vice versa. These individuals often have more serious somatic symptoms, longer disease recovery time, and tend to consume more medical resources and health care costs. Therefore, recognition of depression and anxiety is crucial to improve clinical outcome in FD patients. The aim of this study is to systematically review the association of functional dyspepsia with depression and anxiety.

Methods: This systematic review was reported following the Preferred Reporting Items for Systematic Reviews and Meta-Analyses (PRISMA) criteria. A Literature search was carried out with PubMed and ProQuest databases from 1 January 2010 to 5 October 2020. The outcomes of interest were association of functional dyspepsia with depression and anxiety. The quality of each study was assessed using the Joanna Briggs Institute (JBI) tool.

Results: A total of 13 studies involving 14,076 subjects were included in this review. Almost all of the studies showed that prevalence of depression or anxiety is higher in patients with FD compared to controls. This is implied by a higher mean score on the depression and anxiety questionnaire assessment tools or a positive correlation in the odds ratio. FD is known to affect more females than males, but psychological links were stronger in males. Moreover, prevalence of depression and anxiety symptoms in patients with refractory FD (63.3\% and 61.5\%) was higher compared to non-refractory FD $(20.9 \%$ and $23.3 \%)$ and healthy patients (10\% and $10 \%)$.

Conclusion: There is a significant association of FD with depression and anxiety. Thus, identifying psychological factors in FD patients is essential to help clinicians determine the best choice of treatment and improve the prognosis and quality of life of the patients.
\end{abstract}

Key words: functional dyspepsia - depression - anxiety - psychiatric disorder - systematic review.

Abbreviations: FD: functional dyspepsia; FGID: functional gastrointestinal disorders; BDI: Beck Depression Inventory; BAI: Beck Anxiety Inventory; HAMD: Hamilton Depression Rating Scale; HAMA: Hamilton Anxiety Rating Scale; HADS: Hospital Anxiety and Depression Scale; SAS: Self-Rating Anxiety Scale; SDS: Self-Rating Depression Scale.

\section{INTRODUCTION}

Functional dyspepsia (FD) is one of the most common functional gastrointestinal disorders (FGID), with an estimated prevalence of up to $29.2 \%$ [1]. Functional dyspepsia symptoms were frequently found in health check-up patients [2]. Many studies suggest that FD can interfere with patients' quality of life [3-6]. Disruptions of quality of life could cause many disadvantages, such as decreased performance in daily activities, lack of energy, decreased social activities, and loss of interest in life. Moreover, the health care costs of dyspepsia for society are substantial due to health care seeking, medication, and sick leave costs. Based on a retrospective analysis of payroll and medical health insurance data of more than 300,000 employees over four years, those with FD had higher medical costs and absenteeism and lower productivity than those without FD [7]. Functional dyspepsia patients also inflict significant direct and indirect health costs. A total mean direct yearly annual cost to FD patients was $\$ 699$, which places an economic burden upon the health care system [8]. 
Many factors are known to be associated with FD, one of which is psychiatric disorders [9]. A study by Haug et al. [10] reported that $34 \%$ of FD patients had a psychiatric diagnosis [10]. Anxiety and depression are among the many psychiatric illnesses that are associated with FD. Anxiety disorders are diagnosed in $38 \%$ of FD patients, while depressive disorders are diagnosed in $16 \%$ of FD patients [11]. The pathophysiology in FD comorbid with depression or anxiety is known to result from the brain-gut pathway alteration, and the disturbance is bidirectional [12]. Psychiatric disorders are thought to cause FD symptoms due to corticotropin-releasing hormone stress response, leading to the release of cytokine and could cause gastroduodenal dysfunction [13]. On the other hand, FD symptoms are thought to cause anxiety or depression due to a cytokine response in low-grade gut inflammation, which is postulated to have an important role in driving psychological stress in FD patients $[14,15]$. We can conclude that FD patients comorbid with anxiety or depression are trapped in a vicious cycle. Without proper treatment, both FD and anxiety or depression will continue to get worse and more difficult to treat. Many studies have found a significant association between depression, anxiety, and FD [16, 17]. Functional dyspepsia patients with anxiety and depression comorbidity often have more serious somatic symptoms, longer disease recovery time, and tend to consume more medical resources and health care costs $[8,18,19]$.

It is important to take a holistic approach to FD patients in order to get appropriate treatment. Recognition and treatment of psychiatric comorbidities of FD may be crucial to improve clinical outcome in these patients and alleviate the economic burden upon the health care system. In order to get further insight of clinical relevance of this association, we conducted this review to provide a basis for identifying patients with functional dyspepsia at higher risk of anxiety and depression, and thus will help determine targeted interventions and improve the prognosis and quality of life of these patients.

\section{METHODS}

This study was performed following the Preferred Reporting Items for Systematic Reviews and Meta-Analysis (PRISMA) criteria [20].

A literature search was carried out with PubMed and ProQuest databases from 1 January 2010 to 5 October 2020 using a search strategy that included the terms for 'dyspepsia', 'indigestion', 'depression', and 'anxiety', and 'psychiatric' as presented in Table I. No language restrictions were applied. The authors manually reviewed the reference lists of all articles of interest to identify potential additional studies.

Using the PICOS criteria, studies were included if they: (1) published observational studies that investigated the association between functional dyspepsia and depression and anxiety in individuals >17 years old from 2010-2020; (2) diagnosis of FD was assessed by Rome III or Rome IV criteria; (3) depression was assessed by Self-Rating Depression Scale (SDS), Beck Depression Inventory (BDI), Hamilton Depression Rating Scale (HAMD), and Hospital Anxiety and Depression Scale (HADS) questionnaires; and (4) anxiety was assessed by Self-Rating Anxiety Scale (SAS), Beck Anxiety Inventory (BAI), Hamilton Anxiety Rating Scale (HAMA), and Hospital Anxiety and Depression Scale (HADS) questionnaires. To assess the quality of articles and avoid bias, case reports, review articles, letters, unpublished articles, or studies that were carried out on clinical patients were excluded.

Articles were identified using the key words described above. After removing duplicates using the EndNote X9 program, retrieved articles were screened based on their titles and abstracts. Thereafter, potentially eligible full-text articles were thoroughly assessed using the eligibility criteria described above. Any emerging discrepancies were resolved by consensus among the review team.

The following data were extracted from the studies: (1) first author; (2) country; (3) publication year; (4) study design; (5) age at baseline year; (6) sample size; (7) methods of dyspepsia assessment; (8) methods of depression assessment; and (9) methods of anxiety assessment.

The quality of each study was assessed independently by three authors (T.E., S.D., F.G.S.) using the Joanna Briggs Institute (JBI) tool which was used to assess the quality of the included studies: cross sectional, case-control, and cohort studies [21]. Three authors (T.E., S.D., F.G.S.) independently evaluated whether a study had low or some concerns or high risk of bias with any discrepancies resolved through discussion. The questionnaire included nine questions for cross sectional study, ten questions for case control study and eleven questions for cohort study. The questions contained sample selection, measurement of the condition, identifying confounding factors and strategies to deal with them, outcome assessment criteria and statistical analysis method used. These questions required a yes, no and unclear response. According to these criteria, authors classified the quality of each study as follows: 1) low risk of bias if 3 or less criteria were not met for cross sectional and case control, 4 or less criteria were not met for cohort 2) medium risk of bias if 4-6 criteria were not met for cross sectional and case control, 5-7 or less criteria were not met for cohort or 3) high risk of bias if 7-10 criteria were not met for cross sectional and case control, 8-11 or less criteria were not met for cohort.

\section{RESULTS}

Literature search and characteristics of the included studies

Database searches retrieved 622 articles from two electronic databases (PubMed, ProQuest). A total of 13 articles fulfilled

Table I. Search key words

\begin{tabular}{ll}
\hline Databases & Keywords \\
\hline PubMed & („Dyspepsia”[MeSH Terms] OR „Dyspepsia”[Title/Abstract] OR „Indigestion”[Title/Abstract]) AND („Depression”[MeSH \\
& Terms] OR „Depression”[Title/Abstract] OR „Anxiety”[MeSH Terms] OR „Anxiety”[Title/Abstract] OR „Psychiatric”[Title/ \\
& Abstract]) \\
\hline ProQuest & (su(Dyspepsia OR Indigestion) OR ab(Dyspepsia OR Indigestion) OR ti(Dyspepsia OR Indigestion)) AND (su(Depression \\
& OR Anxiety OR Psychiatric) OR ab(Depression OR Anxiety OR Psychiatric) OR ti(Depression OR Anxiety OR Psychiatric)) \\
\hline
\end{tabular}


the inclusion criteria. The selection process is presented as a flow diagram according to the Preferred Reporting Items for Systematic Reviews (Fig. 1). Table II shows a summary of the studies that have been included. Of the 13 studies included in our analysis, five were case-control studies [22-26], seven were cross-sectional studies [27-33], one was a cohort study [34]. Eight studies were carried out in Asia, three in North America, and two in Europe. The selection process is presented as a flow diagram according to the PRISMA Criteria (Fig. 1).

Studies included in this review recruited adults with ages ranging from 17 to 65 years old. The total number of samples in this study were 14,076 subjects. The assessment for psychiatric disorder and functional dyspepsia used in each study were varied, but the results show a similar pattern. For the assessment of depression and anxiety, the majority of the studies used HADS (eight studies) [23-26, 29-31, 33, 34], followed by HAMD/HAMA (two studies) [22, 24], SDS/SAS (two studies) [27, 28], and BDI/BAI (one study) [32]. Most of the included studies used Rome III criteria as a standard diagnostic for functional dyspepsia, while others used different diagnostic tools. In the retrospective study by Adibi et al., [30] modified Rome III criteria was used and some questions from the Talley Bowel Disease questionnaire were added. Huang et al. [27] used the Rome IV criteria.

\section{Risk of bias assessment}

All thirteen studies included in this review are considered as low risk of bias. Indeed, there are several reasons that could cause a slight bias among these studies. Some studies were suspected to have some confounding factors and there were unclear strategies to deal with it $[27-29,34]$. A few studies neither describe clearly the criteria of inclusion and exclusion, nor the study subject and setting details $[30,33]$. In every case control study, there was no clear data regarding the exposure time, so it was not known whether it was sufficient enough to influence the outcome or not [22-26]. In a cohort study, sample follow up was incomplete and there were no strategies addressed to incomplete follow up [34]. Despite all these reasons, it could be ascertained that these reasons did not cause significant disruption to the results since there were only a few factors that biased each study.

\section{Outcomes of included studies regarding depression and anxiety}

Nine studies reported a mean score on the depression and anxiety questionnaires [22, 24-30, 33]. Almost all studies showed higher mean scores on depression and anxiety questionnaires in patients with functional dyspepsia compared to healthy subjects. As in the study by Huang et al. [27], both mean SAS ( $\mathrm{t}=6.944)$ and SDS $(\mathrm{t}=6.751)$ scores were higher in the FD group than in the healthy group $(\mathrm{p}<0.01)$ [27]. A previous study done by Huang et al. [28] in 2014 stated that mean SAS scores were significantly higher in the FD group $(\mathrm{p}<0.05)$ compared to scores among the general Chinese population. A study by Zhang et al. [22] showed similar results with mean HAMD and HAMA scores significantly higher in FD patients compared to scores of the control group $(\mathrm{p}<0.01)$ [22].

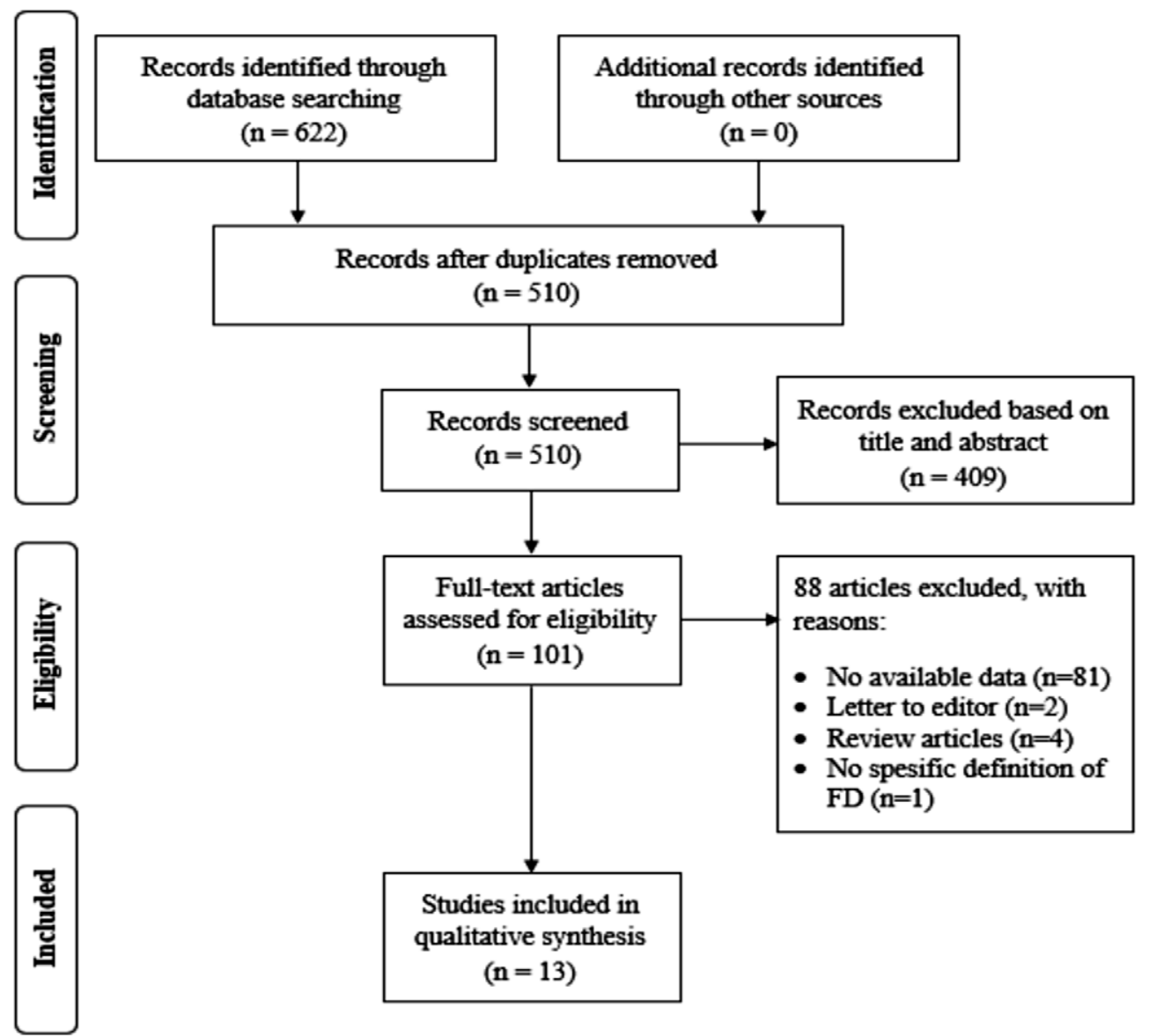

Fig. 1. Flow diagram of the literature search 
Hartono et al. [25] conducted a study to examine the differences in the prevalence and severity of anxiety and depression in patients with FD. Results show that HADS-A $(\mathrm{p}<0.001)$ and HADS-D $(\mathrm{p}=0.03)$ scores among FD patients were higher than those of the control group. Two other studies by Lacy et al. [26] and Choi et al. [29] also support the previous study by showing significant differences between mean scores of HADS in the FD group compared to the control group $(\mathrm{p}<0.001)$.

Some studies reported variables that were slightly different from others. As in the study by Adibi et al. [30], the FD group was divided into two subgroups based on gender. The prevalence of FD was more in females than male, but psychological effects were stronger in males. Of all participants, mean scores of depression $(\mathrm{p}<0.001)$, anxiety $(\mathrm{p}<0.001)$, and psychological distress $(p<0.001)$ were significantly higher in participants with FD than in the control group. Another study by Jiang et al. [24] divided FD into two subgroups based on the duration of disease and severity, namely refractory FD (RFD) and nonrefractory FD (NRFD) [24]. The prevalence of depression and anxiety symptoms in this study was higher in patients with RFD (63.3\% and 61.5\%) than in patients with NRFD $(20.9 \%$ and $23.3 \%)$ or healthy volunteers $(10 \%$ and $10 \%)$. Similarly, HAMA ( $\mathrm{p}=0001)$ and HAMD $(\mathrm{p}=0.003)$ scores, which represent the severity of depression and anxiety symptoms respectively, were also significantly higher in patients with RFD compared to patients with NRFD and healthy volunteers.

Furthermore, four studies reported the odds ratio (OR) between depression and anxiety with functional dyspepsia [23, 31, 32, 34]. A study by Matsuzaki et al. [23] showed that the severity of anxiety was associated with the presence of FD symptoms ( $\mathrm{OR}=1.87)$. Moreover, studies by Pinto-Sanchez et al. [31] and Seyedmirzaei et al. [32] also showed a positive correlation in the OR between depression $(\mathrm{OR}=1.94,2.13)$, anxiety $(\mathrm{OR}=2.18,1.65)$ and $\mathrm{FD}$. A ten-year follow-up cohort study by Aro et al. [34] found that anxiety at baseline was associated with seven fold risk of new onset FD. Characteristics and outcomes of included studies are summarized and presented in Table II.

\section{DISCUSSION}

The majority of the included studies showed a significant association of FD with depression and anxiety [23, 25-33, $35]$. Studies have shown that the mean scores of depression and anxiety are significantly higher among FD patients than in healthy people [24, 27-30]. A systematic review conducted by Hojo et al. [36] showed that treatment with anxiolytics or antidepressants in FD patients improve dyspeptic symptoms significantly. Moreover, a randomized-controlled trial study conducted by Nakamura et al. [37] showed that acotiamide, a drug used for treating postprandial distress syndrome, improves anxiety symptoms in FD patients. A twelve-month therapy with cisapride, a prokinetic drug, had also been shown to significantly improve the depression and anxiety scales in patients with severe dyspepsia [38]. These findings showed an association of FD with depression and anxiety.

Although evidence for an association of FD with depression and anxiety is convincing, the mechanism remains incompletely understood. One of the potential mechanisms involved was through the bidirectional brain-gut pathway. The gut alters brain-inducing anxiety mechanism is through cytokine release secondary to low-grade gut inflammation, which alters central nervous system functioning and induces anxiety [14]. Meanwhile, anxiety induces a corticotropinreleasing hormone stress response that activates eosinophils, promotes eosinophil degranulation, and leads to the release of cytokines such as TNF-alpha in FD, altering gastroduodenal function [13,35]. A trial study by Geeraerts et al. [39] reported that experimentally induced anxiety alters gastric sensorimotor function, including decreased gastric compliance, impaired gastric accommodation to a meal, and increased epigastric symptom scores during a standard nutrient challenge in healthy volunteers.

However, a study performed by Dibaise et al. [33] showed that although the mean scores of anxiety and depression are higher among FD patients than controls, the difference was not statistically significant. This might be because the study included patients who reported having FD symptoms but did not meet Rome III criteria as controls. These patients might have higher depression and anxiety scores than healthy controls, making the score difference between the FD patients and controls insignificant.

A previous study carried out by Adibi et al. [30] showed that the prevalence of FD is less in males than females. Regardless of FD status, females experience depression and anxiety more frequently and more intensely than males [30]. Another study by Choi et al. [29] also showed that female patients have higher mean anxiety and depression scores than male patients, with the severity of epigastric pain correlating with anxiety scores only in female FD patients. One of the most critical factors characterizing an individual biologically male and female is the sex hormone. The sex hormone, in particular estrogen, might play a role in the control of motor and sensory functions of the gastrointestinal tract through direct or indirect action on immune, endocrine, and neuronal pathways as well as interactions with the gut microbiota [40]. The periodic changes in the female sex hormone can affect visceral nociception and cause a change in gastric motility [41]. Estrogen also affects women's emotions and moods. Therefore, female sex hormones might affect visceral pain and gastric motility, supporting the female gender as a risk factor of FD [42].

Functional dyspepsia patients with psychological distress were found to have greater symptom severity, longer recovery time, increased health care costs, and healthcare-seeking behavior [ $8,18,19,43,44]$. A study by Jiang et al. [24] showed that mean depression and anxiety scores are higher in patients with RFD compared to patients with NRFD or healthy controls [24]. This implies that anxiety and depression might predispose unresponsiveness to treatment among FD patients or that RFD patients have a higher risk of developing depression and anxiety. Another study found that FD patients with normal anxiety and depression scores used a median of two drugs. In comparison, those with higher anxiety and depression scores used a median of three drugs [44]. Furthermore, individuals with FD have a lower quality of life as their activities had been limited because of their symptoms. Thus, it is essential to pay more attention to psychological factors in FD patients. 
Table II. Characteristics and outcome of the studies included

\begin{tabular}{|c|c|c|c|c|c|c|c|c|c|c|}
\hline Study & Country & Year & $\begin{array}{l}\text { Study } \\
\text { design }\end{array}$ & $\begin{array}{l}\text { Sample size } \\
(\mathrm{N})\end{array}$ & $\begin{array}{l}\text { Sample } \\
\text { characteristics }\end{array}$ & $\begin{array}{l}\text { Assessment } \\
\text { of dyspep- } \\
\text { sia }\end{array}$ & $\begin{array}{l}\text { Assessment } \\
\text { of depres- } \\
\text { sion }\end{array}$ & $\begin{array}{l}\text { Assessment } \\
\text { of anxiety }\end{array}$ & Outcome & $\begin{array}{l}\text { Risk } \\
\text { of bias } \\
\text { assess- } \\
\text { ment }\end{array}$ \\
\hline $\begin{array}{l}\text { Huang et al. } \\
\text { [27] }\end{array}$ & China & 2020 & $\begin{array}{l}\text { Cross } \\
\text { sectional }\end{array}$ & Total: 759 & $\begin{array}{l}\text { Age: } 18.39 \pm 1.00 \\
\text { Male: } 287 \\
\text { Female: } 472\end{array}$ & Rome IV & SDS $>50$ & $\mathrm{SAS}>50$ & $\begin{array}{l}\text { Depression (SDS) } \\
\text { FD: } 47.81 \pm 9.18 \\
\text { Controls: } 41.85 \pm 8.07 \\
\text { p }<0.01 \\
\text { Anxiety (SAS) } \\
\text { FD: } 45.39 \pm 7.72 \\
\text { Controls: } 40.24 \pm 7.36 \\
\text { p }<0.01\end{array}$ & $\begin{array}{l}\text { Low } \\
(7 / 8)\end{array}$ \\
\hline $\begin{array}{l}\text { Zhang et al. } \\
\text { [22] }\end{array}$ & China & 2020 & $\begin{array}{l}\text { Case } \\
\text { control }\end{array}$ & $\begin{array}{l}\text { FD: } 40 \\
\text { Controls: } 40\end{array}$ & $\begin{array}{l}\text { FD: } \\
\text { Age: } 41.95 \pm 10.94 \\
\text { Male: } 14 \\
\text { Female: } 26 \\
\text { Controls: } \\
\text { Age: } 43.48 \pm 10.86 \\
\text { Male: } 17 \\
\text { Female: } 23\end{array}$ & Rome III & HAMD & HAMA & $\begin{array}{l}\text { Depression (HAMD) } \\
\text { FD: } 8 \text { (4-12) } \\
\text { Controls: } 2.5(1-4) \\
\text { p<0.01 } \\
\text { Anxiety (HAMA) } \\
\text { FD: } 6(3.25-7.75) \\
\text { Controls: } 3(1-5.75) \\
\text { p<0.01 }\end{array}$ & $\begin{array}{l}\text { Low } \\
(9 / 10)\end{array}$ \\
\hline $\begin{array}{l}\text { Matsuzaki et } \\
\text { al. [23] }\end{array}$ & Japan & 2017 & $\begin{array}{l}\text { Case } \\
\text { control }\end{array}$ & $\begin{array}{l}\text { FD: } 40 \\
\text { Controls: } 78\end{array}$ & $\begin{array}{l}\text { FD: } \\
\text { Age: NR } \\
\text { Gender: NR } \\
\text { Controls: } \\
\text { Age: NR } \\
\text { Controls: NR }\end{array}$ & Rome III & HADS $>8$ & HADS $>8$ & $\begin{array}{l}\text { Depression (HADS) } \\
\mathrm{p}>0.05 \\
\mathrm{OR}=1.01 \\
\text { Anxiety (HADS) } \\
\mathrm{p}<0.05 \\
\mathrm{OR}=1.87\end{array}$ & $\begin{array}{l}\text { Low } \\
(9 / 10)\end{array}$ \\
\hline $\begin{array}{l}\text { Choi et al. } \\
\text { [29] }\end{array}$ & Korea & 2017 & $\begin{array}{l}\text { Cross } \\
\text { sectional }\end{array}$ & $\begin{array}{l}\text { FD: } 104 \\
\text { Controls: } 87\end{array}$ & $\begin{array}{l}\text { FD: } \\
\text { Age: } 50.5 \pm 11.3 \\
\text { Male: } 39 \\
\text { Female: } 65 \\
\text { Controls: } \\
\text { Age: } 54.9 \pm 12.1 \\
\text { Male: } 38 \\
\text { Female: } 49\end{array}$ & Rome III & HADS $>7$ & HADS $>7$ & $\begin{array}{l}\text { Depression (HADS) } \\
\text { FD: } 8.4 \pm 0.6 \\
\text { Controls: } 5.9 \pm 0.4 \\
\text { p=0.001 } \\
\text { Anxiety (HADS) } \\
\text { FD: } 7.4 \pm 0.7 \\
\text { Controls: } 5.1 \pm 0.4 \\
\text { p=0.005 } \\
\text { Total HADS score } \\
\text { FD: } 15.8 \pm 1.2 \\
\text { Controls: } 11.0 \pm 0.8 \\
\text { p=0.001 }\end{array}$ & $\begin{array}{l}\text { Low } \\
(7 / 8)\end{array}$ \\
\hline $\begin{array}{l}\text { Adibi et al. } \\
\text { [30] }\end{array}$ & Sweden & 2016 & $\begin{array}{l}\text { Cross } \\
\text { sectional }\end{array}$ & Total: 4,763 & $\begin{array}{l}\text { Age: } 36.87 \pm 8.09 \\
\text { Male: } 2,016 \\
\text { Female: } 2,657\end{array}$ & $\begin{array}{l}\text { Modified } \\
\text { Rome III }\end{array}$ & HADS $\geq 11$ & HADS $\geq 11$ & $\begin{array}{l}\text { Depression (HADS) } \\
\text { Males: } \\
\text { FD: } 8.0 \pm 4.0 \\
\text { Controls: } 5.2 \pm 2.9 \\
\text { p<0.001 } \\
\text { Females } \\
\text { FD: } 8.6 \pm 3.6 \\
\text { Controls: } 6.2 \pm 3.2 \\
\text { p }<0.001 \\
\text { Anxiety (HADS): } \\
\text { Males } \\
\text { FD: } 6.0 \pm 4.3 \\
\text { Controls: } 2.5 \pm 3.0 \\
\text { p }<0.001 \\
\text { Females } \\
\text { FD: } 6.7 \pm 3.5 \\
\text { Controls: } 3.5 \pm 3.5 \\
\text { p }<0.001\end{array}$ & $\begin{array}{l}\text { Low } \\
(7 / 8)\end{array}$ \\
\hline $\begin{array}{l}\text { Dibaise et al. } \\
\text { [33] }\end{array}$ & USA & 2015 & $\begin{array}{l}\text { Cross } \\
\text { sectional }\end{array}$ & $\begin{array}{l}\text { FD: } 151 \\
\text { Controls: } 58\end{array}$ & $\begin{array}{l}\text { FD: } \\
\text { Age: } 46 \pm 17 \\
\text { Male: } 34 \\
\text { Female: } 117 \\
\text { Controls: } \\
\text { Age: } 48 \pm 17 \\
\text { Male: } 15 \\
\text { Female: } 43\end{array}$ & Rome III & HADS $>8$ & HADS $>8$ & $\begin{array}{l}\text { Depression (HADS) } \\
\text { FD: } 7.37 \pm 4.36 \\
\text { Controls: } 6.71 \pm 4.56 \\
\text { p=0.331 } \\
\text { Anxiety (HADS) } \\
\text { FD: } 7.83 \pm 4.23 \\
\text { Controls: } 6.81 \pm 4.06 \\
\text { p=0.117 }\end{array}$ & $\begin{array}{l}\text { Low } \\
(7 / 8)\end{array}$ \\
\hline $\begin{array}{l}\text { Pinto } \\
\text { Sanchez et } \\
\text { al. [31] }\end{array}$ & Canada & 2015 & $\begin{array}{l}\text { Cross } \\
\text { sectional }\end{array}$ & Total: 2,400 & $\begin{array}{l}\text { Age: } 48.27 \pm 17.22 \\
\text { Male: } 899 \\
\text { Female: } 1501\end{array}$ & Rome III & HADS & HADS & $\begin{array}{l}\text { Depression (HADS) } \\
\text { OR=1.94 } \\
\text { Anxiety (HADS) } \\
\mathrm{OR}=2.18\end{array}$ & $\begin{array}{l}\text { Low } \\
(8 / 8)\end{array}$ \\
\hline
\end{tabular}




\begin{tabular}{|c|c|c|c|c|c|c|c|c|c|c|}
\hline \multicolumn{11}{|c|}{ Table II (continued) } \\
\hline $\begin{array}{l}\text { Jiang et al. } \\
{[24]}\end{array}$ & China & 2015 & $\begin{array}{l}\text { Case } \\
\text { control }\end{array}$ & $\begin{array}{l}\text { FD: } 1,341 \\
\text { RFD: } 327 \\
\text { NFRD: } 1,014 \\
\text { Controls: } \\
100\end{array}$ & $\begin{array}{l}\text { FD: } \\
\text { Age: } 40.17 \pm 11.72 \\
\text { Male: } 554 \\
\text { Female: } 787 \\
\text { RFD: } \\
\text { Age: } 41.91 \pm 11.30 \\
\text { Male: } 127 \\
\text { Female: } 200 \\
\text { NFRD: } \\
\text { Age: } 39.60 \pm 11.81 \\
\text { Male: } 427 \\
\text { Female: } 587 \\
\text { Controls: } \\
\text { Age: } 39.83 \pm 12.42 \\
\text { Male: } 45 \\
\text { Female: } 55\end{array}$ & Rome III & HAMD $\geq 7$ & $\mathrm{HAMA} \geq 8$ & $\begin{array}{l}\text { Depression (HAMD) } \\
\text { RFD: } 11.65 \pm 6.51 \\
\text { NRFD: } 7.15 \pm 3.34 \\
\text { Controls: } 1.66 \pm 2.50 \\
\text { p=0.003 } \\
\text { Anxiety (HAMA) } \\
\text { RFD: } 10.84 \\
\text { NRFD: } 6.83 \pm 3.53 \\
\text { Controls: } 2.26 \pm 2.68 \\
p=0.001\end{array}$ & $\begin{array}{l}\text { Low } \\
(8 / 10)\end{array}$ \\
\hline $\begin{array}{l}\text { Aro et al. } \\
{[34]}\end{array}$ & Swedish & 2015 & Cohort & Total: 703 & $\begin{array}{l}\text { Age (baseline): } 53 \\
\text { Age (follow up): } \\
63.2 \\
\text { Male: } 338 \\
\text { Female: } 365\end{array}$ & Rome III & $\begin{array}{l}\text { HADS } \geq 8 \text { : } \\
\text { suspected } \\
\text { HADS } \geq 11 \\
\text { : major }\end{array}$ & $\begin{array}{l}\text { HADS } \geq 8 \text { : } \\
\text { suspected } \\
\text { HADS } \geq 11 \text { : } \\
\text { major }\end{array}$ & $\begin{array}{l}\text { Depression (HADS) } \\
\text { FD at baseline } \\
\text { OR=1.03 } \\
\text { FD at follow-up } \\
\text { OR=4.59 } \\
\text { Anxiety (HADS) FD at } \\
\text { baseline OR=3.67 FD } \\
\text { at follow-up OR=7.32 }\end{array}$ & $\begin{array}{l}\text { Low } \\
(8 / 11)\end{array}$ \\
\hline $\begin{array}{l}\text { Huang et } \\
\text { al.[28] }\end{array}$ & China & 2014 & $\begin{array}{l}\text { Cross } \\
\text { sectional }\end{array}$ & Total: 907 & $\begin{array}{l}\text { Age: NR } \\
\text { Male: } 549 \\
\text { Female: } 358\end{array}$ & Rome III & $\mathrm{SDS}>53$ & $\mathrm{SAS}>50$ & $\begin{array}{l}\text { Depression (SDS) } \\
\text { FD: } 51.57 \pm 8.82 \\
\text { Anxiety (SAS) } \\
\text { FD: } 51.04 \pm 7.53 \\
\text { p<0.05 }\end{array}$ & $\begin{array}{l}\text { Low } \\
(7 / 8)\end{array}$ \\
\hline $\begin{array}{l}\text { Seyedmirzaei } \\
\text { et al. [32] }\end{array}$ & Iran & 2014 & $\begin{array}{l}\text { Cross } \\
\text { sectional }\end{array}$ & Total: 2,210 & $\begin{array}{l}\text { Age: } 43.4 \pm 16.25 \\
\text { Male: } 1049 \\
\text { Female: } 1161\end{array}$ & Rome III & $\mathrm{BDI}>15$ & $\mathrm{BAI}>7$ & $\begin{array}{l}\text { Depression } \mathrm{p}<0.0001 \\
\mathrm{OR}=2.13 \\
\text { Anxiety (BAI) } \mathrm{p}=0.004 \\
\mathrm{OR}=1.65\end{array}$ & $\begin{array}{l}\text { Low } \\
(8 / 8)\end{array}$ \\
\hline $\begin{array}{l}\text { Hartono et } \\
\text { al. [25] }\end{array}$ & Malaysia & 2012 & $\begin{array}{l}\text { Case } \\
\text { control }\end{array}$ & $\begin{array}{l}\text { FD: } 62 \\
\text { Controls: } 62\end{array}$ & $\begin{array}{l}\text { FD: } \\
\text { Age: } 50 \pm 14.3 \\
\text { Male: } 22 \\
\text { Female: } 40 \\
\text { Controls: } \\
\text { Age: } 52.9 \pm 9.9 \\
\text { Male: } 25 \\
\text { Female: } 37\end{array}$ & Rome III & $\mathrm{HADS} \geq 8$ & $\mathrm{HADS} \geq 8$ & $\begin{array}{l}\text { Depression (HADS) } \\
\text { FD: } 5.1 \pm 3.7 \\
\text { Controls: } 3.2 \pm 3.2 \\
\text { p=0.03 } \\
\text { Anxiety (HADS) } \\
\text { FD: } 7.53 \pm 4.2 \\
\text { Controls: } 3.9 \pm 3.4 \\
\text { p }<0.001\end{array}$ & $\begin{array}{l}\text { Low } \\
(7 / 10)\end{array}$ \\
\hline $\begin{array}{l}\text { Lacy et al. } \\
{[26]}\end{array}$ & USA & 2011 & $\begin{array}{l}\text { Case } \\
\text { control }\end{array}$ & $\begin{array}{l}\text { FD: } 121 \\
\text { Controls: } 50\end{array}$ & $\begin{array}{l}\text { FD: } \\
\text { Age: } 50 \pm 15 \\
\text { Male: } 22 \\
\text { Female: } 99 \\
\text { Controls: } \\
\text { Age: } 44 \pm 11 \\
\text { Male: } 4 \\
\text { Female: } 46\end{array}$ & Rome III & HADS & HADS & $\begin{array}{l}\text { Depression (HADS) } \\
\text { FD: } 11.45 \pm 4.57 \\
\text { Controls: } 3.19 \pm 3.34 \\
\text { p<0.001 } \\
\text { Anxiety (HADS) } \\
\text { FD: } 15.42 \pm 8.01 \\
\text { Controls: } 6.59 \pm 4.35 \\
\text { p }<0.001\end{array}$ & $\begin{array}{l}\text { Low } \\
(9 / 10)\end{array}$ \\
\hline
\end{tabular}

SDS: Self-Rating Depression Scale; SAS: Self-Rating Anxiety Scale; FD: functional dyspepsia; HAMD: Hamilton Depression Rating Scale; HAMA: Hamilton Anxiety Rating Scale; HADS: Hospital Anxiety and Depression Scale; BDI: Beck Depression Inventory; BAI: Beck Anxiety Inventory.

\section{Strengths and limitations}

This study has several strengths. First, this study is arguably the most recent update about this topic. This is the first review that includes papers using Rome IV criteria, the most updated diagnostic criteria for FD, as a diagnostic tool. Second, all included studies are considered as low risk of bias, implying the results were more credible. Also, this review includes a large number of samples.

However, this study also has several limitations. First, only observational studies were included, thus our study only provides an association rather than causation. Second, a more diverse sample from every continent is required in this review to be representative of the worldwide population. The included studies in this review mostly originate in Asia, only a few studies were conducted in America and Europe and no study came from Africa and Australia.

\section{CONCLUSIONS}

Based on the data obtained from 13 studies, we conclude a significant association of FD with depression and anxiety. As depression and anxiety seem to play a role in the pathophysiology of FD, it is essential to identify psychological factors in FD to help clinicians determine the best choice of treatment and improve the prognosis and quality of life of the patients. Further studies assessing psychological factors 
and treatment strategies for FD are required to confirm the relationship of FD with depression and anxiety.

Conflicts of interest: None to declare.

Authors' contributions: T.E. designed the study, contributed to the selection of the studies, and wrote the article. S.D., F.G.S contributed to the selection of the studies by performing database searching, extraction of data, and wrote the article. G. contributed to conception and design of the study and to final revision of the manuscript. All authors approved the final draft submitted.

\section{REFERENCES}

1. Mahadeva S, Goh KL. Epidemiology of functional dyspepsia: a global perspective. World J Gastroenterol 2006;12:2661-2666. doi:10.3748/ wjg.v12.i17.2661

2. Kim SE, Kim N, Lee JY, et al. Prevalence and Risk Factors of Functional Dyspepsia in Health Check-up Population: A Nationwide Multicenter Prospective Study. J Neurogastroenterol Motil 2018;24:603-613. doi:10.5056/jnm18068

3. El-Serag HB, Talley NJ. Health-related quality of life in functional dyspepsia. Aliment Pharmacol Ther 2003;18:387-393. doi:10.1046/ j.1365-2036.2003.01706.x

4. Talley NJ, Locke GR 3rd, Lahr BD, et al. Functional dyspepsia, delayed gastric emptying, and impaired quality of life. Gut 2006;55:933-939. doi:10.1136/gut.2005.078634

5. Haag S, Senf W, Tagay S, et al. Is there any association between disturbed gastrointestinal visceromotor and sensory function and impaired quality of life in functional dyspepsia? Neurogastroenterol Motil 2010;22:262e79. doi:10.1111/j.1365-2982.2009.01415.x

6. Gutierrez A, Rodrigo L, Riestra S, et al. Quality of life in patients with functional dyspepsia: A prospective 1-year follow-up study in Spanish patients. Eur J Gastroenterol Hepatol 2003;15:1175-1181. doi:10.1097/00042737-200311000-00005

7. Brook RA, Kleinman NL, Choung RS, Melkonian AK, Smeeding JE, Talley NJ. Functional dyspepsia impacts absenteeism and direct and indirect costs. Clin Gastroenterol Hepatol 2010;8:498-503. doi:10.1016/j.cgh.2010.03.003

8. Lacy BE, Weiser KT, Kennedy AT, Crowell MD, Talley NJ. Functional dyspepsia: the economic impact to patients. Aliment Pharmacol Ther 2013;38:170-177. doi:10.1111/apt.12355

9. Barry S, Dinan TG. Functional dyspepsia: Are psychosocial factors of relevance. World J Gastroenterol 2006;12:2701-2707. doi:10.3748/wjg. v12.117.2701

10. Haug TT, Svebak S, Wilhelmsen I, Berstad A, Ursin H. Psychological factors and somatic symptoms in functional dyspepsia. A comparison with duodenal ulcer and healthy controls. J Psychosom Res 1994;38:281-291. doi:10.1016/0022-3999(94)90033-7

11. Tse AWY, Lai LH, Lee CC, et al. Validation of Self-administrated Questionnaire for Psychiatric Disorders in Patients with Functional Dyspepsia. J Neurogastroenterol Motil 2010;16:52-60. doi:10.5056/ jnm.2010.16.1.52

12. Jones MP, Dilley JB, Drossman D, Crowell MD. Brain-gut connections in functional GI disorders: anatomic and physiologic relationships. Neurogastroenterol Motil 2006;18:91-103. doi:10.1111/j.13652982.2005.00730.x
13. Zheng PY, Feng BS, Oluwole C, et al. Psychological stress induces eosinophils to produce corticotrophin releasing hormone in the intestine. Gut 2009;58:1473-1479. doi:10.1136/gut.2009.181701

14. Koloski NA, Jones M, Kalantar J, Weltman M, Zaguirre J, Talley NJ. The brain-gut pathway in functional gastrointestinal disorders is bidirectional: a 12 -year prospective population-based study. Gut 2012;61:1284-1290. doi:10.1136/gutjnl-2011-300474

15. Liebregts $T$, Adam B, Bredack C, et al. Immune activation in patients with irritable bowel syndrome. Gastroenterology 2007;132:913-920. doi:10.1053/j.gastro.2007.01.046

16. Li Y, Nie Y, Sha W, Su H. The link between psychosocial factors and functional dyspepsia: an epidemiological study. Chin Med J (Engl) 2002;115:1082-1084.

17. Filipović BF, Randjelovic T, Ille T, et al. Anxiety, personality traits and quality of life in functional dyspepsia-suffering patients. Eur J Intern Med 2013;24:83-86. doi:10.1016/j.ejim.2012.06.017

18. Löwe B, Spitzer RL, Williams JBW, Mussell M, Schellberg D, Kroenke K. Depression, anxiety and somatization in primary care: syndrome overlap and functional impairment. Gen Hosp Psychiatry 2008;30:191199. doi:10.1016/j.genhosppsych.2008.01.001

19. Haag S, Senf W, Hauser W, et al. Impairment of health-related quality of life in functional dyspepsia and chronic liver disease: the influence of depression and anxiety. Aliment Pharmacol Ther 2008;27:561-571. doi:10.1111/j.1365-2036.2008.03619.x

20. Moher D, Shamseer L, Clarke M, et al. Preferred reporting items for systematic review and meta-analysis protocols (PRISMA-P) 2015 statement. Syst Rev 2015;4:1. doi:10.1186/2046-4053-4-1

21. Joanna Briggs Institute. Critical-appraisal-tools. Available from: https:// jbi.global/critical-appraisal-tools

22. Zhang $\mathrm{S}, \mathrm{Wu} \mathrm{L}$, Zhang B, et al. Impaired decision-making under risk in patients with functional dyspepsia. J Clin Exp Neuropsychol 2020;42:771-780. doi:10.1080/13803395.2020.1802406

23. Matsuzaki J, Suzuki H, Togawa K, et al. Burden of impaired sleep quality on work productivity in functional dyspepsia. United European Gastroenterol J 2018;6:398-406. doi:10.1177/2050640617726466

24. Jiang SM, Jia L, Lei XG, et al. Incidence and psychological-behavioral characteristics of refractory functional dyspepsia: A large, multicenter, prospective investigation from China. World J Gastroenterol 2015;21:1932-1937. doi:10.3748/wjg.v21.16.1932

25. Hartono JL, Mahadeva S, Goh KL. Anxiety and depression in various functional gastrointestinal disorders: do differences exist? J Dig Dis 2012;13:252-257. doi:10.1111/j.1751-2980.2012.00581.x

26. Lacy BE, Everhart K, Crowell MD. Functional dyspepsia is associated with sleep disorders. Clin Gastroenterol Hepatol 2011;9:410-414. doi:10.1016/j.cgh.2011.02.010

27. Huang ZP, Wang K, Duan YH, Yang G. Correlation between lifestyle and social factors in functional dyspepsia among college freshmen. J Int Med Res 2020;48:300060520939702. doi:10.1177/0300060520939702

28. Huang ZP, Yang XF, Lan LS, et al. Correlation between social factors and anxiety-depression in function dyspepsia: do relationships exist? Prz Gastroenterol 2014;9:348-353. doi:10.5114/pg.2014.47897

29. Choi YJ, Park YS, Kim N, et al. Gender differences in ghrelin, nociception genes, psychological factors and quality of life in functional dyspepsia. World J Gastroenterol 2017;23:8053-8061. doi:10.3748/wjg. v23.i45.8053

30. Adibi P, Keshteli AH, Daghaghzadeh H, Roohafza H, Pournaghshband $\mathrm{N}$, Afshar H. Association of anxiety, depression, and psychological 
distress in people with and without functional dyspepsia. Adv Biomed Res 2016;5:195. doi:10.4103/2277-9175.190936

31. Pinto-Sanchez MI, Ford AC, Avila CA, et al. Anxiety and Depression Increase in a Stepwise Manner in Parallel With Multiple FGIDs and Symptom Severity and Frequency. Am J Gastroenterol 2015;10:10381048. doi:10.1038/ajg.2015.128

32. Seyedmirzaei SM, Haghdoost AA, Afshari M, Dehghani A. Prevalence of Dyspepsia and its Associated Factors Among the Adult Population in Southeast of Iran in 2010. Iran Red Crescent Med J 2014; 16:e14757.

33. Dibaise JK, Islam RS, Dueck AC, Roarke MC, Crowell MD. Psychological distress in Rome III functional dyspepsia patients presenting for testing of gastric emptying. Neurogastroenterol Motil 2016;28:196-205. doi:10.1111/nmo.12709

34. Aro P, Talley NJ, Johansson SE, Agreus L, Ronkainen J. Anxiety Is Linked to New-Onset Dyspepsia in the Swedish Population: A 10-Year Follow-up Study. Gastroenterology 2015;148:928-937. doi:10.1053/j. gastro.2015.01.039

35. Liebregts T, Adam B. Bredack C. et al. Small bowel homing T cells are associated with symptoms and delayed gastric emptying in functional dyspepsia. Am J Gastroenterol 2011;106:1089-1098. doi:10.1038/ ajg.2010.512

36. Hojo M, Miwa H, Yokoyama T, et al. Treatment of functional dyspepsia with antianxiety or antidepressive agents: systematic review. J Gastroenterol 2005;40:1036-1042. doi:10.1007/s00535-005-1687-8

37. Nakamura K, Tomita T, Oshima T, et al. A double-blind placebo controlled study of acotiamide hydrochloride for efficacy on gastrointestinal motility of patients with functional dyspepsia. J Gastroenterol 2017;52:602-610. doi:10.1007/s00535-016-1260-7

38. Abell TL, Cutts TF, Cooper T. Effect of Cisapride Therapy for Severe Dyspepsia on Gastrointestinal Symptoms and Quality of Life: General Discussion. Scand J Gastroenterol Suppl 1993;195:60-63. doi:10.3109/00365529309098330

39. Geeraerts B, Vandenberghe J, Van Oudenhove L, et al. Influence of Experimentally Induced Anxiety on Gastric Sensorimotor Function in Humans. Gastroenterology 2005;129:1437-1444. doi:10.1053/j. gastro.2005.08.020

40. Mulak A, Taché Y, Larauche M. Sex hormones in the modulation of irritable bowel syndrome. World J Gastroenterol 2014;20:2433-2448. doi:10.3748/wjg.v20.i10.2433

41. Kim YS, Kim N. Functional Dyspepsia: A Narrative Review With a Focus on Sex-Gender Differences. J Neutogastroenterol Motil 2020;26:322334. doi:10.5056/jnm20026

42. Kim SE, Kim N, Lee JY, et al. Prevalence and Risk Factors of Functional Dyspepsia in Health Check-up Population: A Nationwide Multicenter Prospective Study. J Neurogastroenterol Motil 2018;24:603-613. doi:10.5056/jnm 18068

43. Hu WHC, Wong WM, Lam CLK, et al. Anxiety but not depression determines health care-seeking behaviour in Chinese patients with dyspepsia and irritable bowel syndrome: a population-based study. Aliment Pharmacol Ther 2002;16:2081-2088. doi:10.1046/j.1365-2036.2002.01377.x

44. Alam L, Naqvi M, Saeed F. Relation of functional dyspepsia with anxiety and depression and its impact on the quality of life of patients. Pak Armed Forces Med J 2019;69:230-235 